\title{
Mapping of small-scale seamounts off Southern Chile
}

\author{
NAtSue AbE' ${ }^{1}$, TOSHIYA FuJIWARA ${ }^{2}$, NAOMI HARADA ${ }^{3}$, \\ MIRAI MR16-09 LEG 2 SHIPBOARD SCIENCE PARTY \\ JAMSTEC, Yokohama, Japan, \\ abenatsu@jamstec.go.jp \\ ${ }_{2.3}$ JAMSTEC, Yokosuka, Japan
}

A bathymetry, gravity, and magnetic survey off southern Chile during the $\mathrm{R} / \mathrm{V}$ Mirai cruise in 2017 provided new information about this area where had been sparsely surveyed. We will present results of newly mapped seamounts on the Antarctic Plate. The seamounts had summit caldera, thus the seamounts were presumed to originate from submarine volcanoes origins. The largest seamount was located at $51^{\circ} 00^{\prime} \mathrm{S}, 79^{\circ} 25^{\prime} \mathrm{W}$. The seamount had a major axis of about $17 \mathrm{~km}$, a minor axis of $10 \mathrm{~km}$, and the strike of the major axis is $\mathrm{N} 45^{\circ} \mathrm{W}$. The water depth of the base of the seamount is about $3900 \mathrm{~m}$ and the summit depth was about $2900 \mathrm{~m}$, thus the relative height was about $1000 \mathrm{~m}$. The seamount was surrounded by a moat with the maximum deep of $100 \mathrm{~m}$. The basal area was about $160 \mathrm{~km}^{2}$ and the volume above the seafloor was about $70 \mathrm{~km}^{3}$. The depth and the diameter of the caldera were $200 \mathrm{~m}$ and $2.5 \mathrm{~km}$, respectively. We observed free-air gravity anomaly of about $+20 \mathrm{mGal}$ at the base of the seamount, and of about $+50 \mathrm{mGal}$ over the top of the seamount, thus the peak-to-trough amplitude of the gravity anomaly produced by the seamount was $30 \mathrm{mGal}$. Our gravity modeling suggested that the seamount mostly consisted of dense basaltic rocks and had been emplaced on lithosphere with elastic thickness. Therefore, the seamount was supposed to erupt near the midocean ridge. The southeastern half of seamount was magnetized in positive direction. On the other hand, for the northwestern half, the magnetization was uncertain because there was no ship track coverage over the portion. We observed magnetic total force and also vector anomaly with amplitudes of about $400 \mathrm{nT}$. Magnetic Anomaly $5 \mathrm{C}$ to $6 \mathrm{~A}$ (Crustal ages: $\sim 16-21 \mathrm{Ma}$ ) of the magnetic lineation were identified along our transit tracks in the vicinity of the seamounts. These identifications are consistent with magnetic isochrons reported from previous studies. 